\title{
BIBLIOTECA ESCOLAR
}

SILVA, Rovilson J.; BORTOLIN, Sueli (org). Fazeres cotidianos na biblioteca escolar. São Paulo: Polis, 2006. 114p.
No Brasil a Biblioteconomia e a Ciência da Informação passaram a se desenvolver mais, como em outras áreas, com a expansão da pós-graduação. Todavia, trata-se de um desenvolvimento que ainda está aquém nas necessidades nacionais. Também como profissão pode-se dizer que no Brasil houve avanços especialmente no setor universitário e nos sistemas de bibliotecas públicas de alguns estados. Mas novamente o que se dispõe está longe de atender o necessário para um desenvolvimento não apenas da profissão mas do próprio país. A área de biblioteconomia escolar é particularmente carente e "soluções" inadequadas procuram ser base para superação, mas não o são. Assim, um livro que enfoque esta área, só pode ser bem vindo não apenas para os bibliotecários mas para todos que se preocupam com a educação.
A obra é produto do esforço de vários autores, com experiência variada na área, unidos pela preocupação de trazer uma contribuição útil, um repensar a situação da biblioteca escolar. Os textos apresentados tratam da matéria de forma simples, clara, direta, em linguagem acessível a leigos, podendo ser útil não apenas para o profissional da área mas também para as equipes pedagógicas das escolas, diretores e mesmos pais que podem ser envolvidos no compromisso de melhorar a qualidade de ensino. Biblioteca escolar deve ser uma cobrança para que se busque a sonhada melhoria e se possa formar melhor a cidadania. Possivelmente pelo caráter mais de divulgação e de propor aspectos essenciais para discussão, a bibliografia dos vários capítulos tende a ser predominantemente em língua portuguesa (mais textos brasileiros) e de livros. Pelo menos um capítulo 
poderia ter evidenciado a situação em países estrangeiros e as muitas pesquisas de avaliação de estratégias usadas no exterior para desenvolver a Biblioteca Escolar. Fica a sugestão para a próxima edição do livro.

Além da sucinta apresentação foram reunidos 10 capítulos. No primeiro deles, os organizadores tecem considerações sobre a leitura e a biblioteca escolar que, como lembram bem, carece de mais pesquisas e discussões, sobre seu papel, especialmente na formação de leitores. É um organismo acadêmico que precisa ter um perfil melhor delineado, com pessoas adequadamente preparadas para cumprir suas múltiplas funções.

Solange P. de Queiroz trata do que se denomina alfabetização em informação (Information literacy) indispensável hoje para a inclusão de todo cidadão e para um melhor aproveitamento do próprio ensinoaprendizagem que se espera ocorra no sistema educacional, imprescindível para formar pessoas com autonomia de aprendizagem, que saibam usar as estratégias e meios para sua educação permanente. A biblioteca escolar pode ser a base para tal progresso.

É inegável o papel do bibliotecário no que concerne a seu potencial para ser um dos atores na formação do leitor, para tanto, como lembram Elizandra Martins e Sueli Bortolini (Capítulo 3), é necessário que o profissional esteja ciente da ênfase de seu trabalho deve recair na leitura e na articulação com seus usuários e com os membros da equipe educacional, principalmente os professores. A continuidade surge naturalmente no Capítulo 4 em que Oswaldo Francisco de Almeida Junior discute qual o perfil que deve ter o bibliotecário escolar em termos de aparência, cuidados físicos e principalmente de comportamentos desejáveis para bom desempenho e atendimento aos vários grupos de usuário aos quais deve oferecer o devido apoio e ambiente para desenvolvimento.

Em seguida, Elizandra Martins apresenta a biblioteca escolar como espaço para a mediação de leitura, começando por lembrar que como tal, mesmo quando existe tem sido tratada com muita negligência. Algumas indicações para busca de criar e ativar o espaço de leitura são feitas pela autora. No Capítulo 6, Sueli Bortolin faz uma série de considerações e cobranças para que realmente sejam melhor cuidadas as bibliotecas escolares para que se tenha um país de leitores, "uma nação em que a leitura ocupe um lugar privilegiado" (p. 73). Em texto breve (Capítulo 7), Rovilson J. da Silva dá continuidade à questão de formação de leitores que é uma questão que requer estratégias, conhecimentos, competências, habilidades além do envolvimento. O Capítulo seguinte leva a assinatura de Selma Alice F. Ellvein e enfoca um problema complexo, com muitas pseudo soluções e não resolvido no Brasil. Trata- 
se da pesquisa escolar. Como podem conduzir bem os alunos em tais atividades os profissionais responsáveis por sua formação são cientificamente analfabetos ou no início da soletração? Esta questão não é enfocada, são oferecidas algumas considerações sobre o papel de educadores, pais, professores e bibliotecários. O desconhecimento de tecnologias de ensinoaprendizagem para isto parece uma marca nacional e está a requerer melhor capacitação dos vários profissionais envolvidos. Oswaldo F. de Almeida Júnior continua a tratar da matéria no capítulo seguinte apontando aspectos críticos da situação brasileira.

Ainda no mesmo tema, fechando o livro, o Capítulo 10 de Ana Lúcia A. de O. Bicheri e Selma A. F. Ellwein apresenta a pesquisa via Internet com suas vantagens e desvantagens. Entretanto vale lembrar que as pesquisas na área apontam deturpações na formação do leitor-escritor se o processo não for adequadamente conduzido.

É uma obra que pode ser útil em vários cursos, não apenas de Biblioteconomia, como é o caso de Psicologia Escolar, Pedagogia, Letras etc. São textos para iniciar os temas que deverão ser aprofundados pelos docentes, pela pesquisa e pela leitura de outros textos mais avançados. Por serem textos de poucas páginas viabi- lizam uma ampla variedade de seminários em que podem servir de ponto de partida.

\section{Geraldina Porto Witter}

Universidade Camilo Castelo Branco UNICASTELO

witter@uol.com.br

Title: School library

Titulo: Biblioteca Escolar 